Вестник ВГУ. Серия: Право

УДК 342.9

DOI https://doi.org/10.17308/vsu.proc.law.2020.3/2984

\title{
ПООЩРИТЕЛЬНАЯ ПРАВОВАЯ ПОЛИТИКА В СФЕРЕ ГОСУДАРСТВЕННОЙ ГРАЖДАНСКОЙ СЛУЖБЫ: ВОПРОСЫ ПРАВОТВОРЧЕСТВА
}

\author{
Е. А. Титова \\ Воронежский государственньй университет \\ Поступила в редакцию 25 июля 2020 г.
}

\begin{abstract}
Аннотация: рассматриваются некоторые аспекты правотворческой борль реализации поощрительной правовой политики государства в сбере государственной гражданской службы. Предлагается для обсуждения идея о разработке фбедерального закона "О поошрении и поошрительном производстве в систеле государственной гражданской службы Российской Федерации». Обозначены возможные пути решения проблель нормативно-правовой неопределенности понятия "заслуга государственного гражданского служащего", в частности фборлула заслуженного поступка в систеле государственной гражданской службь.

Ключевые слова: государственная гражданская служба, поощрительная правовая политика, поощрительные норль, заслуга, борлула заслуженного поступка в систеле государственной гражданской службы.
\end{abstract}

\begin{abstract}
: some aspects of law-making form of implementation of the state's encouraging legal policy in the sphere of public civil service are considered. The idea of developing a federal law "About the encouragement and encouraging proceedings in the system of public civil service of the Russian Federation" is also proposed for discussion. Possible ways of solving the problem of regulatory uncertainty of a notion of "merit of a civil servant", in particular, the formula of a well-deserved act in the system of public civil service, are indicated. Key words: public civil service, encouragement legal policy, encouraging rules, merit, the formula of a well-deserved act in the system of public civil service.
\end{abstract}

Указ Президента РФ «Об основных направлениях развития государственной гражданской службы на 2019-2021 годы» ${ }^{1}$ среди приоритетных линий ее совершенствования закрепляет положение о стимулировании гражданских служащих к повышению эффективности своей профессиональной служебной деятельности и развитии системы государственных правовых и социальных гарантий в системе государственной гражданской службы.

Известно, что юридическая природа института государственной службы восходит к приоритету публичного интереса, интереса государства. Тем не менее в свете продолжающейся реформы государственной службы возникает необходимость поддержания баланса между ограни-

${ }^{1}$ Об основных направлениях развития государственной гражданской службы на 2019-2021 годы : указ Президента РФ от 24 июня 2019 г. № 288 // Собр. законодательства Рос. Федерации. 2019. № 26. Ст. 3410.

(C) Титова Е. А., 2020 
чениями и запретами как элементами статуса гражданского служащего и системой мотивации его труда. Решению такой задачи способствует проведение эффективной поощрительной правовой политики в сфере государственной гражданской службы.

По мнению А. В. Малько, поощрительная правовая политика в целом представляет собой обоснованную с точки зрения науки, последовательную, системную деятельность государственных и негосударственных структур по созданию эффективного механизма поощрительно-правового регулирования, направленного на юридическое одобрение заслуженного поведения субъектов ${ }^{2}$.

В свою очередь, под поощрительной правовой политикой в сфере государственной службы предложено понимать научно обоснованную, последовательную и системную деятельность государственных и негосударственных структур по созданию эффективного механизма поощрительно-правового регулирования государственно-служебных отношений, направленного на активизацию и юридическое одобрение заслуженного поведения государственных служащих. Отмечено, что поощрительная правовая политика государства выступает одной из наиболее важных и перспективных разновидностей правовой политики, занимающей центральное место в регулировании общественных отношений. Ее эффективная реализация - надежное средство проведения реформ в государстве ${ }^{3}$.

Поощрительная правовая политика в сфере государственной гражданской службы на современном этапе призвана сформировать четкие ориентиры, систему ценностных представлений о том, какую государственную службу необходимо создавать в новых исторических условиях, каким требованиям должна отвечать ее эффективная модель.

Признаки настоящей модели государственной службы определил А. А. Гришковец: наличие обширного и детально разработанного законодательства о государственной службе, требования к конкурсному порядку замещения должностей государственной службы, стабильность положения государственного служащего, престиж государственной службы в обществе, наличие государственного органа (системы органов) по делам государственной службы и др. ${ }^{4}$ Обозначение требований, предъявляемых к институту государственной службы, безусловно, необходимо для понимания основных направлений его развития. Однако полагаем, что практическая целесообразность таких условий обоснована с точки зрения совершенствования уже действующей в стране модели государственной службы. Ю. Н. Старилов справедливо заметил: в настоящий момент «... даже без мелких сомнений, можно констатировать наличие именно

${ }^{2}$ См.: Малько А. В. Поощрительная правовая политика в современной России : необходимость формирования // Современное право. 2010. № 12. С. 30.

${ }^{3}$ См.: Малько А. B., Типикина E. B. Поощрительная правовая политика в сфере государственной службы : проблемы оптимизации // Современное право. 2012. № 7. C. 70-71.

${ }^{4}$ См.: Гришковеи $A$. А. К вопросу о служебном праве // Государство и право. 2013. № 4. C. 11-12. 


\section{Вестник ВГУ. Серия: Право}

модельных свойств российской государственной службы. Более того, если приняты и уже продолжительное время действуют в стране законы, устанавливающие систему и виды государственной службы, ее принципы, детализированный порядок прохождения государственной службы, весьма утонченный и одновременно масштабный статус государственных служащих, - как же здесь не задуматься над самой моделью государственной службы в России?»

Возможно, не в такой совершенной вариации, в какой она предстает в доктринальных представлениях, но, действительно, определенная модель государственной службы в нашей стране сегодня уже сложилась и функционирует. Существующие и новые конструктивные предложения, касающиеся приведения ее в соответствие с требованиями практики государственного управления, будут способствовать повышению эффрективности и результативности действия такой модели с точки зрения целей и задач российской системы государственной службы.

Правотворчество выступает одним из важнейших направлений современной поощрительной правовой политики. Представители юридической науки отмечают, что в условиях усиления демократических начал государства необходим качественно новый тип поощрительного нормативно-правового регулирования ${ }^{6}$. Исследование особенностей поощрительных норм служебного законодательства необходимо для правильного представления о механизме воздействия поощрения на профессиональное самосознание гражданского служащего и его влиянии на эффективность и результативность служебной деятельности в долгосрочной перспективе.

Выступая в качестве специального средства поощрительной правовой политики, поощрительные нормы обнаруживают свою ценность в преодолении ограничений, сдерживающих позитивно направленную активность личности, раскрытии ее творческих начал, стимулировании прогрессивного развития общества, мобилизации заложенного в нем потенциала. Отмечено, что данные нормы, разработанные в соответствии с основными идеями и направлениями поощрительной правовой политики государства, обладают свойствами целостности, относительной завершенности, что делает возможным единообразное и долговременное их применение ${ }^{7}$.

Анализ действующего федерального и регионального служебного законодательства показал отсутствие базовых понятий, касающихся поощрения гражданских служащих. В ст. 55 Федерального закона «О государ-

${ }^{5}$ Старилов Ю. Н. Служебное право России : уже реальность или пока научная гипотеза? // Правовая наука и реформа юридического образования. 2013. № 3 (26). C. 106.

${ }^{6}$ См.: Дьяченко В. Ф. Поощрительно-правовая политика современной России : общетеоретический анализ : автореф. дис. ... канд. юрид. наук. Краснодар, 2006. C. 19.

${ }^{7}$ См.: Там же. С. 8. 


\section{Административное право и процесс}

ственной гражданской службе Российской Федерации»8 законодателем дается лишь перечень мер поощрения, которые могут применяться за безупречную и эффрективную гражданскую службу.

Мысль о принятии на феедеральном уровне кодифицированного правового акта, регулирующего награды и поощрения, не единожды была высказана представителями юридической науки ${ }^{9}$. Соглашаясь с такой идеей, отметим, что принятие специального закона, систематизирующего правовые основы поощрения в системе государственной гражданской службы, например федерального закона «О поощрении и поощрительном производстве в системе государственной гражданской службы Российской Федерации», является не менее насущной потребностью современного правового регулирования.

Предлагаемый нормативный правовой акт должен иметь следующую структуру. В первой главе необходимо закрепить общие положения, касающиеся поощрения в системе государственной гражданской службы: его цели, задачи, принципы, порядок действия фредерального закона, определение основных понятий, используемых в законе («поощрение гражданского служащего», «заслуга гражданского служащего», «безупречная и эффективная гражданская служба», «особые отличия в гражданской службе»), и их признаки. Вторая глава должна быть посвящена описанию конкретных моделей заслуженного поведения и мер поощрения, при этом необходимо обозначить связь каждой меры поощрения с определенным основанием по принципу «заслуга - мера поощрения», а также порядку оценки эффекктивности и результативности профессиональной служебной деятельности гражданских служащих. Особое внимание должно быть уделено нормам, закрепляющим порядок разработки долгосрочных федеральных и региональных целевых программ, направленных на совершенствование методологической основы проведения такой оценки. Необходимо придать ее результатам, превышающим ожидаемый положительный результат деятельности служащего, статус самостоятельного основания для направления независимой экспертной комиссией соответствующего постановления представителю нанимателя для рассмотрения вопроса о поощрении, установив его обязанность

${ }^{8}$ О государственной гражданской службе Российской Федерации : федер. закон от 27 июля 2004 г. № 79-ФЗ (в ред. от 16.12.2019) // Собр. законодательства Рос. Федерации. 2004. № 31. Ст. 3215.

${ }^{9}$ См., например: Дьяченко В. Ф. Правовое регулирование общефедеральной поощрительной системы // Право и государство : теория и практика. 2007. № 1 (25). С. 57-64 ; Малько А. В. Указ. соч. С. 29-32 ; Караваев А. Н. Совершенствование института поощрения в государственно-служебных отношениях // Вестник Самарского юрид. ин-та. 2013. № 3 (11). С. 97-101; Сытюгина В. А. Наградная политика современной России : проблемы формирования и перспективы развития // Вестник ТГУ. Серия: Гуманитарные науки. 2013. Вып. 12 (128). С. 481-488 ; Антонова E. B., Струсь K. А. Правовые основы в сфрере поощрительного санкционирования : пути оптимизации // Право и государство : теория и практика. 2014. № 4 (112). C. 81-85. 


\section{Вестник ВГУ. Серия: Право}

в определенный законом срок направить в адрес экспертной комиссии мотивированное решение по данному вопросу. Положения третьей главы нормативного правового акта должны быть посвящены поощрительному производству, а именно: регламентировать его целевое назначение, задачи, функции, принципы, круг участников, стадии, сроки совершения определенных действий и процедуры в целом, а также гарантии реализации права гражданского служащего на поощрение.

В исследованиях поощрения и поощрительной правовой политики в системе государственной службы значительное внимание традиционно уделяется заслуженному поведению как основанию применения соответствующих мер.

Так, А. В. Малько и Е. В. Типикина, рассматривая вопросы оптимизации поощрительной правовой политики в сфере государственной службы, определяют заслуги государственного служащего (служебные заслуги) как добровольные, желательные, сознательно-волевые, добросовестные, общественно полезные, социально активные правомерные поступки государственного служащего, связанные со сверхисполнением им своих служебных обязанностей либо с достижением общепризнанных полезных результатов, превосходящих по своим масштабам результаты обычной добросовестной (безупречной) службы и выступающие основанием для применения поощрения ${ }^{10}$.

Е. В. Трофимов указывает, что заслуга как основание награждения обладает атрибутивным признаком социальной полезности, которому в правовой системе коррелируют признаки правомерности (включая снятую за малозначительностью неправомерность) и презюмируемой виновности $^{11}$. Выделение такого признака заслуги, как вина в ее совершении, ученый объясняет следующим образом: «...в правомерном деянии, заслуживающем награды по объективным характеристикам, виновное отношение к содеянному презюмируется, если в процессе оценки деяния не обнаружена ненадлежащая субъективная сторона. Таким образом, виновность заслуги можно считать ее признаком, но с той оговоркой, что виновность заслуги предполагается, если в ходе наградного производства не будет выявлено иное» ${ }^{12}$.

Заслуженное поведение выступает единственным фактическим и, по-

196 сле его правовой оценки, юридическим основанием применения поощрения в той или иной форме. Иное правовое основание, такое как наступление определенного события (юбилейная дата, праздничный день и т. п.), относится к награждению.

Заслуженный поступок - деяние в форме действия, имеющее материальный состав. Здесь нельзя недооценивать значение причинно-след-

${ }^{10}$ См.: Малько А. В., Типикина Е. В. Указ. соч. С. 72.

${ }^{11}$ См.: Трофбимов E. В. Характеристика заслуги как основания награждения // Современное право. 2011. № 2. С. 75.

${ }^{12}$ Tроббимов E. В. Наградное право (Общая часть) : электронное учеб. пособие. СПб., 2014. C. 84. URL: https://elibrary.ru/item.asp?id=36725480 (дата обращения: 09.05.2020). 
ственной связи между положительным сверхправомерным поведением и наступившими полезными «последствиями», так как именно такой признак позволяет правоприменителю грамотно квалифицировать заслуженный поступок и предоставить поощрение служащему, который действительно этого достоен.

Более того, существует необходимость в выработке и последующем закреплении на федеральном уровне служебного законодательства формулы заслуженного поступка в системе государственной гражданской службы, отражающей следующие аспекты.

Во-первых, такая формула должна максимально охватывать все возможные составы заслуженного поведения гражданского служащего, обладая при этом нормативно-правовой определенностью.

Во-вторых, в содержание данной формулы следует включить юридическую характеристику моделей заслуженного поведения в системе государственной гражданской службы - безупречной и эффрективной гражданской службы, особых отличий в гражданской службе. К сожалению, до настоящего времени смысл данных правовых конструкций законодателем не раскрыт, в силу чего последние остаются предметом научных дискуссий. Более того, особые отличия в гражданской службе выступают основанием для единственного вида поощрения гражданского служащего - внеочередного присвоения классного чина. Примечательно, что ни данный вид заслуженного поведения, ни разновидность поощрения не содержит ст. 55 Федерального закона «О государственной гражданской службе Российской Федерации». Они закреплены Указом Президента РФ от 1 фревраля 2005 г. № 113 (в ред. от 30.09.2013) «О порядке присвоения и сохранения классных чинов государственной гражданской службы Российской Федерации федеральным государственным гражданским служащим ${ }^{13}$. Внеочередное присвоение классного чина гражданским служащим субъектов РФ регулируется региональным законодательством с разной степенью определенности понятия особых отличий в гражданской службе ${ }^{14}$.

В-третьих, указанная формула должна содержать стандарты применения конкретных мер поощрения государственного гражданского слу-

${ }^{13}$ Рос. газета. 2005. 3 фревр. ; 2013. 15 фревр.

${ }^{14}$ См., например: Об особых отличиях в гражданской службе : указ губернатора Ярославской области от 8 августа 2014 г. № 351 // Документ-Регион. 2014. 15 авг. ; Об утверждении Положения о присвоении классных чинов государственной гражданской службы Ямало-Ненецкого автономного округа государственным гражданским служащим в качестве меры поощрения : постановление губернатора Ямало-Ненецкого автономного округа от 25 февраля 2011 г. № 22-ПГ (в ред. от 23.10.2019) // Красный Север (спецвып.). 2011. 3 марта ; О государственной гражданской службе Воронежской области : закон Воронежской области от 30 мая 2005 г. № 29-ОЗ (в ред. от 20.12.2019) // Коммуна. 2005. 31 мая ; О порядке присвоения и сохранения классных чинов государственной гражданской службы государственным гражданским служащим Еврейской автономной области : закон Еврейской автономной области от 26 января 2005 г. № 442-ОЗ (в ред. от 27.09.2019) // Собр. законодательства ЕАО. 2005. № 4 . 


\section{Вестник ВГУ. Серия: Право}

жащего. Выступая одним из путей решения проблемы неограниченного усмотрения поощряющего субъекта, предложенная формула будет способствовать оптимизации поощрительного производства в системе государственной гражданской службы, конкретизации поощрительных норм служебного законодательства, выработке единого подхода к юридической квалификации заслуженного поведения гражданских служащих.

C нашей точки зрения, заслуга государственного гражданского служащего представляет собой профессиональную служебную деятельность гражданского служащего, отвечающую требованиям безупречности и эфрфективности, связанную с положительным сверхправомерным поведением, результатом которого выступают конкретные позитивные преобразования сферы общественных отношений, являющейся объектом гражданской службы на соответствующей должности.

Дискуссия о том, какая государственная служба нужна российскому обществу, далека от завершения. Поиск ее оптимальной модели, акцентирующей внимание на правах граждан, принщипах правового государства и гражданского общества, учитывающей опыт развития государственной службы европейских стран, показывающей значимость системы заслуг, продолжается и сегодня. Определенная роль в достижении такой цели отведена поощрительной правовой политике как одному из средств повышения эффективности и результативности профессиональной деятельности государственных гражданских служащих. Надежные основы реализации такой политики формируются именно в процессе правотворчества. Проблематика совершенствования механизма служебного поощрения за десятилетия продолжающейся реформы института российской государственной службы не утратила своей актуальности. Модернизация нормативно-правовой базы поощрения гражданских служащих как одно из перспективных направлений поощрительной правовой политики государства должна найти свою реализацию, прежде всего, в повышении качества технико-юридического оформления поощрительных норм служебного законодательства. Это выступает основным условием эффрективного использования стимулирующего потенциала поощрения как средства мотивации к достижению высоких результатов профессиональной служебной деятельности.

Реформирование законодательства о поощрении в системе государственной гражданской службы должно сопровождаться качественным и своевременным информированием служащих о соответствующих изменениях, при этом разъяснение новых требований должно способствовать формированию в сознании гражданского служащего понимания необходимости и значения проводимых преобразований ${ }^{15}$. Кроме того, такое понимание не может базироваться на авторитарном убеждении в необходимости нововведений и искусственном их возведении в ранг идей-

${ }^{15}$ См.: Пушкарева Г. В. Идейно-ценностный механизм реформирования государственной службы // Государственное управление. Электронный вестник. 2017. Вып. № 63. С. 187-188. 
но-ценностных установок, навязываемых извне. Необходимо выстроить такую систему коммуникации между представителем нанимателя и гражданским служащим, которая позволит каждому из них оценить целесообразность проводимой государством поощрительной правовой политики с точки зрения открывающихся перспектив реализации индивидуальных ожиданий в сфере профессионального служебного роста.

Воронежский государственный университет

Титова Е. А., аспирант кафбедры административного и административного прочессуального права

E-mail: tea993@yandex.ru
Voronezh State University

Titova E. A., Post-graduate Student of the Administrative and Administrative Procedural Law Department

E-mail: tea993@yandex.ru 